\title{
To Honor and Inform: Addressing Cultural Humility in Intercultural Music Teacher Education in Canada
}

\author{
Lori-Anne Dolloff
}

\begin{abstract}
In this chapter I address the need for reshaping the way we think about Indigenous inclusion in the intercultural curriculum. While Canada has prided itself on its multicultural heritage, the nation's relationship with the First Peoples - First Nations, Inuit and Métis - has been immoral, genocidal and assimilationist. The 2015 publication of the findings of the Truth and Reconciliation Commission's Calls to Action details a way forward from the colonial patriarchy of the past. Education in general, and music education in particular are charged with finding ways to incorporate Indigenous knowledge, perspectives and history into the curriculum. After an introduction to the issues of the marginalization of Indigenous voices I discuss several arts-based curricular and extra-curricular initiatives that reframe intercultural music education. I propose that developing cultural humility in music teacher education will be a step forward in the decolonization of our teaching and learning spaces. This includes a move from generic cultural competencies toward an attitude of 'Cultural Humility'. Cultural Humility is discussed as an attitude toward engagement with peoples of cultures other than one's own. The stance is based on life-long, self-reflective inquiry, and seeks to disrupt the power imbalance that defines 'othering', seeking to establish partnerships and collaboration.
\end{abstract}

Keywords Cultural humility · Intercultural education · Music education · Truth and reconciliation $\cdot$ Indigenous issues

I am a second-generation settler on the land we know as Canada. I would like to acknowledge the ancestral keepers of the land on which I live and work:

The sacred land on which the University of Toronto, Faculty of Music operates has been a site of human activity for 15,000 years. This land is the territory of the Huron-Wendat, the Seneca, and most recently, the Mississaugas of the Credit River. The territory was the subject of the Dish With One Spoon Wampum Belt Covenant, an agreement between the

L.-A. Dolloff $(\bowtie)$

Faculty of Music, University of Toronto, Toronto, ON, Canada

e-mail: lori.dolloff@utoronto.ca

H. Westerlund et al. (eds.), Visions for Intercultural Music Teacher Education, Landscapes: the Arts, Aesthetics, and Education 26,

https://doi.org/10.1007/978-3-030-21029-8_9 
Iroquois Confederacy and the Ojibwe and allied nations to peaceably share and care for the resources around the Great Lakes. Today, the meeting place of Toronto is still the home to many indigenous people from across Turtle Island and I am grateful to have the opportunity to work on this land. (Statement developed in consultation with the elders in residence at the University of Toronto available at: https://memos.provost.utoronto.ca/ statement-of-acknowledgement-of-traditional-land-pdadc-72/)

I wish to further acknowledge that I am writing this chapter during the year that Canada is celebrating 150 years of nationhood, a celebration not without contention for it erases the thousands of years of nations that existed in the land we call Canada prior to colonization by Western European countries. This historical erasure and the means by which it was achieved are evident in everything from history textbooks to national celebrations, from the puerile, caricatured manner that Indigenous people are portrayed as sports mascots, to the ways that indigenous music has been censured, appropriated in performance, and indiscriminately consumed.

In this chapter I address current issues for music teacher education that are grounded in a need to reconcile intercultural curriculum policies in music education, as currently practiced, with the reclaimed musical and cultural identities of Indigenous peoples in Canada. This is framed within the movement in Canada toward reconciliation of relationships with Indigenous peoples. Issues in the provision of music education in schools and communities include claims of cultural appropriation as music teachers include acontextual or improperly pan-Indigenous music into their programs, without the voices or lives of Indigenous peoples as part of a discussion around inclusion, or as a contextualizing resource for the music. Many of Canada's First Peoples have traditions of familial or local 'ownership' of individual songs and dances. It is considered inappropriate for other groups of First Peoples, let alone non-Indigenous peoples to perform those songs. The goal of ongoing efforts must be to honor the Indigenous peoples and their cultural protocols as well as to inform ongoing practice as educators seek to include the music and voices of Indigenous experience in non-indigenous music classes.

In seeking a path forward to this goal, I aim to disrupt the rhetoric of cultural reconciliation to move toward an attitude of cultural humility. Following a brief discussion of the role of education in the erasure of Indigenous culture in Canada, I will propose "Cultural Humility" as the framework of our music education response to historical abuse. As inheritors of educational systems that both suppressed Indigenous reality, and exploited certain cultural art forms, participants in current teacher education programs, both instructors and students, need examples of current national and local efforts to re-organize education and teacher education. Examples will be included throughout this chapter as resources for curriculum development in university music teacher education, and as possible models for musical engagement in the university classroom. 


\section{A Brief History of Residential Schooling}

First, a bit of context. Although colonization has resulted in many forms of cultural - and sometimes literal - genocide, there has been an ongoing willful ignorance of the Indigenous experience of colonization in many parts of the world. Canadian national focus has at last been firmly drawn to the trauma caused by the educational colonial practice of residential schooling. The history of residential schooling is not in the distant past; residential schools operated from 1840 to 1996. During this time 15,000 First Nations, Inuit, and Métis children were taken from their homes, many forcibly by social workers accompanied by the police force. These schools were often in isolated communities sometimes hundreds of miles from the children's homes. They were forbidden to speak their native language, their traditional clothes were burned, and their hair, worn long in cultural traditions, was cut. The punishments for speaking languages other than English were strapping, starvation, and isolated confinement. In addition to these various kinds of physical and emotional abuse, many survivors of residential schooling speak of sexual abuse. The children were taught that they were less human than those in power, and that their traditional ways were evil, demonic and to be exterminated. In fact, the Canadian policy was to 'kill the Indian in the child' in order to save the child.

The lingering emotional trauma is evident in the following quote from a witness to testimony of a survivor of the 'education' of residential schooling.

\footnotetext{
I know someone who was in residential school [...] and I know how ashamed she is of being Native, and the deep hatred she has for herself because of her schooling. It seems like every single child who did not die was left without a soul, and who pays the price for that? Everyone. The pain filters through the generations and touches us all. ("Anonymous" respondent on the blog of "Jill" a non-indigenous witness to a truth-telling session cited in Robinson and Martin 2016, p. 45)
}

\section{The Truth and Reconciliation Commission (TRC)}

After many failed attempts to bring this miscarriage of educational goals and cultural genocide to light, including a Royal Commission in 1994, the Canadian government mandated the Truth and Reconciliation Commission of Canada to document the allegations surrounding residential school experiences, and the legacy of this schooling. A brief summary of the work of the commission follows:

- The commission operated from 2009 to 2015

- Court-mandated hearings recorded the stories of survivors and intergenerational survivors of Canada's governmental instituted Residential Schools

- Judge Murray Sinclair, First Indigenous High Court Justice (1988), headed the commission hearings 
- Thousands of hours of statements were recorded from over 7000 survivors, including documentation of artifacts and music

The documentation will be housed with participants' permission at the National Centre for Truth and Reconciliation in Winnipeg. Further, the commission's process resulted in 94 Calls to Action. Addressed to the government and national institutions, these calls are presented as a blueprint for a way forward, and several are recommendations for educational settings. But these proposals and actions are not without controversy. They are premised on the notion of reconciliation - a return to right relationships; the responsibility for reconciliation is fraught with emotional and legal pitfalls.

\section{Reconciliation and Education}

Amagaolik (2012) argues that a focus on reconciliation presupposes a right relationship to which to return. Certainly, colonial history of the last 150 years, particularly in the history of education, boasts no such right relationship. Indigenous artistic practices were treated with mistrust and superstition, and were thus banned. The Indigenous knowledge of the land was ignored, except in cases of extreme need for survival, and traditional wisdom and teaching ways were not included in the education of Indigenous children. Thus, we need to assume a posture of conciliation. Amagaolik describes conciliation as the effort to overcome mistrust and ill will, and to become compatible (2012, p. 91). Is there a role for music making in bridging mistrust and ill will?

Although I am basing my work on the Canadian context, this is not only a North American issue. Indigenous peoples the world over have been subjugated and their histories erased (Maracle 2015). The work of Alexis Kallio with Sami peoples in Finland (2013), and Bartleet et al. (2016a, b) in Australia, among others, speak of the same intergenerational trauma, loss of identity and social issues. Sami musician, Sofia Jannok sees music as an integral part of moving past colonialism. In an interview entitled "Life Beyond Colonialism", Jannok states:

The national media in Sweden are only now opening their eyes to what is happening in Sápmi, because music is bringing these things to the fore. But music has always been an essential part of the decolonization work that Sápmi has undertaken for as long as I have lived and long before my time. (Blomqvist 2016, online article)

The effects of nationalist canons of music also have the effect of homogenizing repertoire and shutting out voices of minority and marginalized voices. Hebert and Kertz-Welzel (2012) explore the results of a move toward creating state-affirming national repertoires, which often silence other realities towards hegemonic reinforcement of patriotism and assimilation into a unified nation-state. Their study echoes the discourse surrounding colonialization in many parts of the world.

Yet, there is a need to beware of forced dualisms, or essentializing either the Indigenous or the Colonizer. Citing Orner (1992), Madden and McGregor remind 
us that thinking in dualisms is a Western-European construct, often positioning Colonizers in a stance of power over Indigenous peoples. In this discussion of curriculum, however, there is an additional issue. Who are included in the dualism? Whose perspectives are excluded? Which Indigenous perspectives are we representing? There is a reason why we list First Nations, Inuit and Métis (FNMI) peoples when we discuss Indigenous Canada. Each of these designations is a collective of local traditions, including sometimes widely varying perspectives. And, even as there is a diversity of indigenous cultures, so too there is a diversity of colonizing cultures and newcomer participants to the colonial project known as Canada. As Madden and McGregor caution,

\begin{abstract}
A brief reading of scholarly literature that focuses on non-Indigenous peoples [...], however, reveals a situation in which the term non-Indigenous is often synonymous with white and of European heritage. The binary opposition then becomes Indigenous/white European, as opposed to Indigenous/non-Indigenous, and regardless of the order the terms are presented, Indigenous can be investigated as the abject [sic.]. From this vantage point, the term non-Indigenous excludes a discussion of the complex experiences of peoples of color who simultaneously participate in and are subject to the colonial project while facing marginalization themselves, as well as unique decolonizing sites, strategies, and goals that may be available from this standpoint. (2013, p. 380)
\end{abstract}

So, it is not a matter of Indigenous/Non-Indigenous/Classical/Non-Classical or Formal/Informal materials and pedagogies. Addressing the need for conciliation, for creating a relationship, disrupting power relationships and overcoming mistrust, requires a deconstruction and reconstruction of music education.

Many of our current flailing attempts to address Indigenous issues do not overcome this deep mistrust. Many continue to inflame it as we add and stir panindigenous musics to the curriculum, grabbing songs and music from the 'global songbook'. Moreover, the addition of indigenous material in the music curriculum cannot just be a unit of listening to decontextualized pan-aboriginal music as suggested in many curriculum guidelines. That does little to: address the centuries of prohibiting drumming, dancing and singing in traditional styles; draw attention to contemporary Indigenous artists creating ongoing artistic expressions; or the ongoing social issues facing Indigenous communities.

\title{
4 Becoming Engaged as a Learner
}

In June 2009, I was invited to 'go North' and teach in the schools of Iqaluit, the capital city of the territory of Nunavut. Nunavut is the newest political territory established in Canada, the first to be locally governed by Indigenous people - the Inuit. Not being well acquainted with the particulars of modern Inuit life, I was uncertain about what I could add to the musical lives of the children in this community. After my first visit, it was evident that I needed to work at contextualizing my teaching and materials in the local context, and I have returned 17 times since June 2009, teaching in schools, music camps and teacher development sessions. I 
have enjoyed the challenges of creating musical materials that reinforce the local language -Inuktitut, and collaborating to create yearly festival performances that included music in English, French and Inuktitut, dealing with themes that speak to the community. The collaboration resulted in bringing a local drum dancer to teach at the university of Toronto, in local high schools and to teach and perform as part of a cultural massed choir event with the Toronto District School Board. In March 2013, I was accompanied by two graduate students who taught alongside me, and immersed themselves in the schools for a week. All of these 'events' are secondary to the ongoing effect of decolonializing my attitudes and waking me up to the appalling continuing effects of colonialism on the Indigenous peoples of Canada. I have recounted the specifics of several of these visits in previous research (Dolloff 2016), and theorized my reflections as a movement toward 're-(in)forming' and decolonializing my teaching practice.

I became determined to bring issues relevant to the effects of colonialism on the Indigenous peoples of Canada to my practice as a music teacher educator. Since I started my travels north I am often asked to come and share music that I have learned during the visits I made to the Arctic. I have done so in collaboration with a Torontobased Inuk colleague, Raigelee Alorut, on many occasions. I did not understand this collaboration as cultural appropriation because I was framing my work to introduce groups to the cultures of the Inuit and encouraging students to seek out and listen to the artists that I showcased through video, or in the children's songs that I taught them to sing. Increasingly, however, I am feeling uneasy with Southern groups performing indigenous music outside of Indigenous gatherings and contexts. For years prohibitions of indigenous cultural expression in many countries have resulted in incarceration, physical trauma, and even death of Indigenous peoples - most famously, perhaps, when the spiritual ritual known as the Ghost Dance was seen as a threat to the US government and precipitated the showdown that ended in the 1890 massacre at Wounded Knee, as Wente (2017) reminds us. When non-indigenous groups publicly perform music that was formerly prohibited, they are moving beyond cultural appropriation, they are gaining cultural capital from something that was denied to its originators. Wente, an indigenous film producer and radio commentator spoke recently about a film produced circa 1894, documenting the Ghost Dance. The indigenous performers were in regalia and danced with passion. However, what the public failed to understand as they consumed this culture was that this same group of dancers could have been imprisoned for performing this dance if it had not taken place as part of a documentary filming (Wente 2017).

My colleague Raigelee Alorut was a guest artist at the Faculty of Music, and led a throat singing, drum dancing ensemble for a term. She felt validated by being able to share her music. Other Inuit did not agree; Tanya Tagaq, renowned throat singer and vocal artist, reportedly told Raigelee, that she would never teach throat singing to Qallunaat [non-Inuit]. This gave Raigelee pause, but, as she worked through the issue, she realized that in teaching the music she is celebrating being able to perform it (Alorut and Dolloff 2016). Raigelee's addition to the university curriculum framed as a 'world music' ensemble was problematic. In team teaching this course with Raigelee, she and I ensured that much of the two hour session each week included 
stories of the experience of colonization of the North, the history of the songmaking, and current issues in the North. This was a different mandate from the rehearsal format of a performance ensemble, but important to both of us in our effort to bring Indigenous knowledge of the North to the university students, to challenge the often romanticized popular notions of the 'Great White North'.

\section{The Colonial Curriculum: A Canonic Fantasy}

In a discussion of addressing the canon of university music education, Madrid (2017) problematizes the inclusion of Ibero-American music in the music history curriculum. He rejects the inclusion of 'marginalized music' in the colonial framework that seeks to homogenize the way music is viewed. To those who would claim that inclusion of world music constitutes expanding the canon, Madrid responds that this view presupposes that:

[the] canon is actually a list of works or a given repertory. However, [...] the canon is an epistemology; it is a way of understanding the world that privileges certain aesthetic criteria and that organizes a narrative about the history and development of music around such criteria and based on that understanding of the world. In other worlds, the canon is an ideology more than a specific repertory. (2017, p. 125)

So, following Madrid, merely incorporating indigenous music into music classrooms, without reorienting the teaching-learning context to incorporate indigenous epistemology is an exercise in re-inscribing colonialism, 'new wine in old skins' if you will. This is the effect of current efforts to 'indigenize' the music academy: replacing white bodies with indigenous bodies, and graciously making space for indigenous titles to the lists of performance repertoire, all with the conductor firmly on the podium, sometimes joined by a 'guest' artist. Although this would seek to respond to the Calls to Action, it does not adequately address the issue of the power differential. Indigenous voices are still guests allowed into the academy, rather than part of the foundation of the enterprise.

\section{Indigenizing or Decolonializing Music Education?}

I choose to look at curriculum reform in music teacher education not from an indigenizing perspective, nor from a postcolonial framework, but rather from a decolonization framework. The goal of decolonializing thinking and doing is to continue re-inscribing, embodying and dignifying those ways of living, thinking and sensing that were violently devalued or demonized by colonial, imperial and interventionist agendas as well as by postmodern and altermodern internal critiques (Baretto 2011 cited in Gaztambide-Fernandez 2012). This approach means that the structure of engagement must be deconstructed and reconstructed in collaboration with musical 
communities of practice. Music education taught within the framework of cultural competence or cultural relevance addresses the bodies who are in the room, but does not address the erased history of the First Peoples of Canada, particularly in areas where there are no students who identify as Indigenous. However, foregrounding the multiple voices of the indigenous experience is a responsibility if we are truly going to redress past actions. Several current initiatives within the Canadian arts scene express an aim to address the historical indigenous experience. An examination within the music teacher education classroom can provide material for discussion, and offer possibilities for deconstructing continuing institutional initiatives to add 'indigeneity' to curriculum in order to inform our own practice.

The National Arts Council of Canada is offering grants for collaborative projects aimed at bringing Indigenous voices to the fore. Collaborators in such projects do not always enjoy a decolonialized experience. Take for example the ballet "Going Home Star", a work commissioned by the Royal Winnipeg Ballet and the Truth and Reconciliation Commission. When asked why TRC would want a project like this in the context of one of the most Western European art forms, TRC commissioner Marie Wilson reportedly replied that the Commission wanted the history to be brought to the people who would attend ballet, who would not hear it otherwise. Likewise, Robinson attests that:

Music performance $[\ldots]$ has the ability to foster audience identification and empathy with a colonial history that non-Aboriginal Canadians may feel removed from. (2014, p. 299)

To create the score, composer Christos Hatzis collaborated with throat singer Tanya Tagaq and Northern Cree Singers. However, the collaboration was problematic because it faced performance issues such as the indigenous performers not reading traditional notation. Also, to accommodate the strict requirement that ballet music to be subject to the dancers' need for consistency, Hatzis sampled Tagaq's voice, and the Northern Cree drums, and another performer activated those elements in the performance. The perception of erasing the indigenous performers in the actual performance was handled by having them perform solo on stage prior to each act. Further, at each performance, there were counselors, elders and other health care providers to ensure care for indigenous people for whom this performance of their history created trauma. As Robinson reminds us:

[What inclusionary or collaborative performance] too often assumes is that shared affective, physiological responses (crying, clapping, ovating) signify a common emotion [...] however, such responses may have strikingly different efficacies for Indigenous and settler audience members. Just as it is important not to conflate the social efficacy of collaborative creative processes with the social efficacy of their resultant performances, it is equally essential not to elide differences between audience members' shared affective responses. (2014, p. 280)

There continues to be ongoing discussion about the efficacy of this project (See the Creative Collaborations website: http://creativecollaboration.ca/going-homestar-partners/). 


\section{Moving from Cultural Competence to Cultural Humility}

One of the popular frames for '[multi]-[inter]-[poly]-[cultural]' music education (the labels we use are a topic for another paper) has been 'cultural competence'. First derived from business contexts, cultural competence often speaks to a set of skills to be learned to aid communication and business negotiations in a culturally respectful way (Tervalon and Murray-Garcia 1998). The connotation of the word 'competence' implies a list of skills that can be learned. Emmanuel (2003), among others, has developed curricula for intercultural competence based on a business model that moved through identifiable stages to evaluate a student's cultural 'development'. Deardorff (2006) examined the definitions of cultural competence to seek a consensus definition. She found that there was not complete agreement on the exact components of the construct, that different populations of professionals, administrators or academics valued different components of a definition. She did, however, propose that cultural competence is a complex, contextually defined construct, and posits a move away from globally defined skills, towards an institutionally specific definition.

Even with this evolving definition of cultural competence, which moves away from observable checklists of skills to be acquired toward valuing less quantifiable affective response and attitudes, I prefer another framework as we decolonialize the music education agenda. I propose that we need to steer away from the discourse of cultural competencies in all musics toward the discourse of 'cultural humility'. While cultural competence emerged from a business model and aimed at culturally ethical interaction, the notion of cultural humility has emerged in the health-care literature owing to the need to assist health care professionals in ethically and compassionately caring for diverse populations (Tervalon and Murray-Garcia 1998). Tervalon and Murray-Garcia speak to the difference between cultural competence and cultural humility, and their work suggests to me the benefits of the latter for music education:

\footnotetext{
While cultural competence speaks to abilities and understandings, cultural humility speaks to attitude, inquiry and spirit. Cultural humility is proposed as a more suitable goal in multicultural [medical] education. Cultural humility incorporates a lifelong commitment to self-evaluation and self-critique, to redressing the power imbalances in the [patientphysician] dynamic, and to developing mutually beneficial and nonpaternalistic [clinical] and advocacy partnerships with communities on behalf of individuals and defined populations. $(1998$, p. 123)
}

More recently, Deardorff (2015), writing after her decade of research on cultural, and later intercultural competence publication, points toward the promise of the stance of cultural humility as she poses questions about the definitions of intercultural competence. She writes:

Is it possible to arrive at one universally accepted definition, given the myriad of contexts and perspectives? Or should the focus be not so much on defining ICC but perhaps on cultural humility - of how to approach others with the recognition that ICC is indeed a lifelong developmental process? 
This final question is congruent with the goal of nurturing life-long learning in teacher education. As the groups we teach throughout of career are continually changing, the notion that cultural humility provides a model of approaching diverse groups holds promise for teacher education.

\section{Teaching for Cultural Humility}

Ross posits that cultural humility generally includes three components: knowledge, attitude and skills (2010, p. 315). These components are all critical for teacher education. Culturally situated musical knowledge includes the sociological background of music and music-making within a cultural practice, as well as the historical and political cultural history of the people who make the music. In the case of Canada's indigenous population, this includes the history of colonialism, the suppression of cultural expression, and knowledge about traditional and contemporary music making within First Nations/Inuit/Métis communities. Knowledge must not be constrained to so-called 'museum' music making practices, in which historical practices are frozen in past traditions of performing. I believe that the conversation of reconciliation must not only make an effort to understand and acknowledge the past, but also support and recognize current artists within our classrooms.

The attitude component of cultural humility addresses the issues of how we as practitioners perceive and conceptualize the 'Other'. Drawing on the work of health care educators, Ross gives an excellent summary of the many attitudes that I propose are as relevant to music teacher education as to health care: practitioners' subconscious and conscious bias and stereotyping, recognition of his or her privilege, and understanding about community mistrust that is borne out of historical and institutional practices (Juarez et al. 2006; Kumas-Tan et al. 2007; Tervalon and Murray-Garcia 1998; Wear 2003 in Ross 2010, p. 318). There are two senses in which we need to avoid bias and stereotypical attitudes: those towards the music and those towards groups of learners.

Classical music has been privileged within institutions since the inception of music programs in Canadian universities. Indeed, in many North American universities, admission is based on a skillful classical (or more recently jazz) audition. Incoming students, required to make a long-term commitment to learning a particular genre of music, are being asked to upend their attitude toward classical music as the pinnacle of musical achievement, and their own privileged status as university students to recognize a more inclusive attitude toward music and music makers. This is not a new idea in the discourse on music teacher education, but as long as we keep classical music as the gateway for university music teacher education, it is a discussion we will need to have again, and again.

Finally, the musical and pedagogical skills that embody cultural humility include: new ways of listening; new modes of music teaching that depart from the way most of us were taught; and a willingness to engage in lifelong learning of the multitude ways of making music, actively learning from others, and reinventing our practice 
as we incorporate new musical voices and expressions in our curriculum. I see echoes of cultural humility in the work of Dion (2007) who uses a "pedagogy of remembrance" to focus on a relationship between pre-service teachers and Indigenous peoples as a basis for decolonizing education. Rather than loading the curriculum with 'indigenous' materials of which the teacher has little or no understanding, she begins by asking teachers to write, draw or reflect on their representation of Indigenous peoples. These are then held up to Indigenous-produced representations to expose gaps in knowledge, any paucity of understanding, and problematic stereotypical images that colonialism has left us with (Dion 2007, p. 331).

In assessing our implicit stereotypes, take, for instance, our notions of Indigenous music. North Americans are fed stereotypes from text-book series, film scores, and other 'indigenous-inspired' compositions. Compare that with works created by Indigenous youth in response to a music education challenge to write a song as a response to Mi'gmaw poet Rita Joe's moving poem, "I lost my talk". Joe's poem is a reflection on the loss of language that resulted from her being taken to residential school. (Videos of the powerful response songs may be found at https://nac-cna.ca/ en/ritajoesong). These youth-driven songs demonstrate the complexity of Indigenous music, incorporating traditional drums and country and western guitar, and drawing from hip hop to create their songs. "Gentle Warrior" is a particularly poignant song fusing traditional vocables, pow wow drums and traditional dress with rock-band and casual dress while re-visiting Joe's home and celebrating her awards and accomplishments (National Arts Centre of Canada 2015. See https://nac-cna.ca/en/ ritajoesong/gentle-warrior).

Or consider the work of Chris Derksen, a classically trained Indigenous cellist who moves the orchestra from the foreground of music-making tradition to place the pow wow drum at the center of the musical conversation. In describing her creation of a new genre, Derksen says, "I wanted to take all of my heritage and all of my traditional learnings - that includes Western classical learning - and put them together" (Deerchild 2015).

Ross proposes a framework of experiential learning for social-work students in order to facilitate and promote the learning of an attitude of cultural humility. This framework consists of a seminar that explores the aspects of cultural humility in relation to cultural communities, and fieldwork or experiential learning. While Ross' work is predicated on the actual communities in which her students would engage in professional social work practice, I propose that there is much to be learned from her approach for music education students. Though experiential learning often occurs in the 'field', music teacher education classrooms are rife with opportunities for experiential learning. In the context of developing knowledge of Canadian Indigenous cultures, one project that influences both knowledge and attitude is the 'Blanket project'. This project, designed by Kairos Canada (https://www. kairosblanketexercise.org), was developed to make tangible the brutal experience and effects of colonization on First Peoples in Canada. Participants stand on blankets representing the land of Canada. Some participants are labelled settlers, others indigenous peoples. As the leaders take away land, and declare some participants 
dead, the precarity of indigenous life and history is brought home. Having spoken with students, community members and family members who have participated in a Blanket Exercise, consensus suggests that no one is left unchanged by the experience. When 1st-year music teacher education students experience a Blanket Exercise in Introduction to Music Education Class, attitudes and expectations are challenged from the beginning of professional learning. Education then becomes a question of: what knowledge and skills do I need to develop in order to address the responsibility to acknowledge and respond to the inequities and imbalances that I have seen?

Ross (2010) further stresses the imperative of self-reflection. Self-reflection has become commonplace in the literature, yet it is often without structure. For Ross, self-reflection must be systematic and subject to dialogue with peers and instructors. Not only does self-reflection aid the student in recognizing and verbalizing learning, it offers the opportunity to make decisions about evolving goals based on changing perspectives. As Ross writes:

Through self-reflection, students and practitioners are encouraged to relinquish the role of expert, work actively to address power imbalance in communication, to create respectful and dynamic partnerships with the community, and ultimately become the student of the community. (2010, p. 318)

Although Ross is reflecting on service learning in the field, setting in place these habits in teacher education can begin with meaningful reflective exercises during in-course experiences of music teacher education.

\section{Conclusions}

There is a national imperative in Canada to address and engage with issues of reconciliation in all levels of education. Music teacher education can respond to this imperative by framing learning experiences within the discourse of cultural humility. This framing necessitates that the teacher educator actively engages in his/ her own development in the three components: knowledge, attitudes and skills. Through sustained engagement and work in communities of music-making practice, the teacher educator not only engages in his/her own professional development, but models the commitment to teaching from a place of cultural humility. Ruben Gaztambide-Fernández suggests,

educators are called upon to play a central role in constructing the conditions for a different

kind of encounter, an encounter that both opposes ongoing colonization and that seeks to heal the social, cultural, and spiritual ravages of colonial history. (2012, p. 42)

I propose that this construction demands an attitude of cultural humility, not simply a checklist of competencies if we are truly going to decolonize the effects of colonial history for Indigenous, Settler and Newcomer populations worldwide. In music this means learning new ways of listening, the inclusion of new voices, and reflecting on our own assumptions and biases. I see these as imperatives for music education, and by extension for music teacher education. They change the canon both in 
content and in methodology, but as Sto'lo scholar Lee Maracle maintains, decolonizing means "doing everything differently" (Maracle 2017).

The conversation continues....

Acknowledgements I am indebted to Ms. Hayley Jane, graduate of the University of Toronto for introducing me to the concept of Cultural Humility.

\section{References}

Alorut, R., \& Dolloff, L.-A. (2016, October 7-10). Creating a narrative of reconciliation through the arts: Listening to stories of oppression, responding with stories of engagement. Paper presented at the Inuit Studies Conference, Memorial University, St. Johns, Newfoundland.

Amagaolik, J. (2012). Reconciliation or conciliation? An Inuit perspective. In Speaking my truth (Vol. 1). Ottawa: Aboriginal Healing Foundation.

Baretto, J.-M. (2011). In Commemoration October 12, 1492: Manifesto of Decolonial aesthetics. In Critical legal thinking. [Online]. http://criticallegalthinking.com/2011/10/12/in-commemoration-october-12-1492-manifesto-of-decolonial-aesthetics-2/. Accessed 9 June 2017.

Bartleet, B.-L., Bennett, D., Power, A., \& Sunderland, N. (Eds.). (2016a). Engaging first peoples in arts-based service learning. New York: Springer.

Bartleet, B.-L., Sunderland, N., \& Carfoot, G. (2016b). Enhancing intercultural engagement through service learning and music making with indigenous communities in Australia. Research Studies in Music Education, 38(2), 173-191.

Blomqvist, R. E. (2016). Decolonization in Europe: Sami musician Sofia Jannok points to Life beyond Colonialism. In Uneven Earth: Tracking environmental injustice [Online]. http:// unevenearth.org/2016/11/decolonisation-in-europe/. Accessed 25 May 2017.

Deardorff, D. K. (2006). The identification and assessment of intercultural competence as a student outcome of internationalization. Journal of Studies in International Education, 10(3), 241-266.

Deardorff, D. (2015). International competence: Mapping the future research agenda. International Journal of Intercultural Relations, 48, 3-5.

Deerchild, R. (interviewer). (2015). Cellist Cris Derksen creates new genre with orchestral Pow wow. Unreserved. [Online]. http://www.cbc.ca/radio/unreserved. Accessed 14 Feb 2017.

Dion, S. (2007). Disrupting Molded images: Identities, responsibilities and relationshipsTeachers and indigenous subject material. Teaching Education, 18, 329-342.

Dolloff, L.-A. (2016). A Qallunaaq on Baffin Island: A Canadian experience of decolonizing the teacher. In B.-L. Bartleet, D. Bennett, A. Power, \& N. Sunderland (Eds.), Engaging first peoples in arts-based service learning (pp. 133-146). New York: Springer.

Emmanuel, D. (2003). An immersion field experience: An undergraduate music education course in intercultural competence. Journal of Music Teacher Education, 13(1), 33-41.

Gaztambide-Fernández, R. (2012). Decolonization and the pedagogy of solidarity. Decolonization: Indigeneity, Education \& Society, 1(1), 41-67.

Going Home Star. (2015). [Online]. http://creativecollaboration.ca/navigating-collaborative-tensions-and-cultural-trauma-in-going-home-star/going-home-star-research-abstract/. Accessed $14 \mathrm{Feb} 2017$.

Hebert, D. G., \& Kertz-Welzel, A. (Eds.). (2012). Patriotism and nationalism in music education. Farnham: Ashgate.

Juarez, J. A., Marvel, K., Brezinski, K. L., Glazner, C., Towbin, M. M., \& Lawton, S. (2006). Bridging the gap: A curriculum to teach residents cultural humility. Family Medicine, 38(2), 97-102. 
Kairos Canadian Ecumenical Justice Initiatives. (2017). What is the blanket exercise? A teaching tool to share the historic and contemporary relationship between indigenous and nonindigenous peoples in Canada [Online]. https://www.kairosblanketexercise.org. Accessed 15 Jan 2018.

Kallio, A. A., \& Partti, H. (2013). Music education for a nation: Teaching patriotic ideas and ideals in global societies. Action, Criticism, and Theory for Music Education, 12(3), 5-30.

Kumas-Tan, Z., Beagan, B., Loppie, C., MacLeod, A., \& Frank, B. (2007). Measures of cultural competence: Examining hidden assumptions. Academic Medicine, 82(6), 548-557.

Madden, B., \& McGregor, H. (2013). Ex(er)cising student voice in pedagogy for decolonizing: Exploring complexities through duoethnography. Review of Education, Pedagogy, and Cultural Studies, 35(5), 371-391.

Madrid, A. L. (2017). Diversity, tokenism, non-canonical musics, and the crisis of the humanities in U.S. Academia. Journal of Music History Pedagogy, 7(2), 124-130.

Maracle, L. (2015). Memory serves, and other essays. Edmonton: Newest Press.

Maracle, L. (2017). Invited lecture to graduate students at the University of Toronto. Toronto: Edward Johnson Building.

National Arts Centre of Canada. (2015). [Video] Mighty warrior. Carter Chiasson, producer [Online]. https://nac-cna.ca/en/ritajoesong/gentle-warrior. Accessed 21 July 2017.

Orner, M. (1992). Interrupting calls for student voice in 'Liberatory' education: A feminist poststructuralist perspective. In C. Luke \& J. Gore (Eds.), Feminisms and critical pedagogy (pp. 74-89). New York: Routledge.

Robinson, D. (2014). Feeling reconciliation, remaining settled. In E. Hurley (Ed.), Theatres of affect (pp. 275-306). Toronto: Playwrights Canada Press.

Robinson, D., \& Martin, K. (Eds.). (2016). Arts of engagement: Taking aesthetic action in and beyond the Truth and Reconciliation Commission of Canada. Waterloo: Wilfred Laurier Press.

Ross, L. (2010). Notes from the field: Learning cultural humility through critical incidents and central challenges in community-based participatory research. Journal of Community Practice, $18,315-335$.

Tervalon, M., \& Murray-Garcia, J. (1998). Cultural humility versus cultural competence: A critical distinction in defining physician training outcomes in multicultural education. Journal of Health Care for the Poor and Underserved, 9(2), 117-125.

Wear, D. (2003). Insurgent multiculturalism: Rethinking how and why we teach culture in medical education. Academic Medicine, 78(6), 549-554.

Wente, J. (2017). Inclusion over appropriation: Indigenous art and reconciliation. Keynote presentation, Toronto District School Board Arts Alive Indigenous Focus Day, February 17, 2017, Central Toronto Academy, Toronto, Canada.

Open Access This chapter is licensed under the terms of the Creative Commons Attribution 4.0 International License (http://creativecommons.org/licenses/by/4.0/), which permits use, sharing, adaptation, distribution and reproduction in any medium or format, as long as you give appropriate credit to the original author(s) and the source, provide a link to the Creative Commons licence and indicate if changes were made.

The images or other third party material in this chapter are included in the chapter's Creative Commons licence, unless indicated otherwise in a credit line to the material. If material is not included in the chapter's Creative Commons licence and your intended use is not permitted by statutory regulation or exceeds the permitted use, you will need to obtain permission directly from the copyright holder.

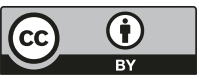

